\title{
BUSNIESS VALUES AND MOTIVES OF IMMIGRANT AGRICULTURAL ENTREPRENEURS IN SWEDEN
}

\author{
Henrik Barth ${ }^{1}, \mathrm{PhD}$, Assistant Professor in Industrial Management; Ghazal Zalkat ${ }^{2}$, \\ MSc Agronomy \\ ${ }_{1,2}$ Halmstad University, Sweden
}

\begin{abstract}
The agri-food sector in Sweden, as in much of Europe, faces dramatic pressure to promote entrepreneurship, especially in rural areas where population aging and population decline pose grave economic threats to local communities. One solution is the government policy of supporting the entrepreneurial ambitions of newly arrived immigrants. The policy is seen as doubly beneficial: support for rural areas and support for immigrants not yet prepared to enter the regular workforce. Immigrant entrepreneurship seems to have the potential to lessen the harmful effects of current socio-economic challenges. This paper examines the immigrant entrepreneurship experience in the agri-food sector in Sweden. A qualitative research approach is used to evaluate interviews with 25 immigrant entrepreneurs on the various factors that motivated them to become selfemployed entrepreneurs. The main factors are the lack of other employment opportunities, the desire for work autonomy and flexibility, and the chance for a better standard of living. The results show that personal characteristics and previous entrepreneurship experience are the best predictors of business success. The paper concludes with a call for a model for immigrant entrepreneurship and for more government reforms and policies aimed at supporting the immigrant entrepreneur.
\end{abstract}

Key words: Immigrant entrepreneurs, Agri-food sector, rural area, motivation factors, business value. JEL code: available on: L26, Q10.

\section{Introduction}

The agricultural sector employs more than one billion people worldwide and accounts for $3 \%$ of global GDP. According to the Food and Agricultural Organization of the United Nations, the sector requires increased investment, especially in new and improved technologies, if it is to maintain the worldwide food supply (FAO, 2018). Yet even rural areas in the wealthier countries in the European Union (EU) are at risk of socio-economic marginalization and desertification. For example, according to the Swedish Board of Agricultures, rural areas in Sweden have experienced substantial economic and demographic changes in the last three decades (Jordbruksverket, 2018; Hedlund and Lundholm, 2015).

\section{Background}

\section{Agricultural entrepreneurship and the agricultural entrepreneur}

A much-discussed subject among researchers, when the focus is on these challenges, is the concept of agricultural entrepreneurship (Lans et al., 2013; Vik and McElwee, 2011). What is agricultural entrepreneurship? Answers vary. Seuneke et al. (2013) relates the concept to the development of non-agricultural business by established, multifunctional farms. Other researchers point to the expansion of traditional agricultural activities to entrepreneurial activities such as new product development (e.g., organic farming and functional foods) and business innovations (e.g., distribution and marketing) (EIP-AGRI, 2016; Vik and McElwee, 2011). The theme running through these descriptions is that agricultural entrepreneurship is the process of founding new organizations or revitalizing older organizations by seizing market opportunities (Gries and Naude, 2011).

A related question is: What characteristics and values do agricultural entrepreneurs exhibit in their business activities? Again, answers vary. For example, in a study of entrepreneurial characteristics in European agricultural workers, Pindado and Sanchez (2017) found that while some agri-entrepreneurs have weaker entrepreneurial capabilities than non-agricultural entrepreneurs,

\footnotetext{
${ }^{1}$ Corresponding author: E-mail: Henrik.Barth@hh.se, Phone: +46-70 6606186.
} 
new entrants (although not established agri-entrepreneurs) in the agricultural sector are just as entrepreneurial as their counterparts in other sectors.

\section{Immigration and rural Europe}

In 2017 many European countries granted protected status to numerous asylum seekers: Germany (325 400), France (40 600), Italy (35 100), Austria (34 000), and Sweden (31 200) (Eurostat, 2018). The expectation, and hope, was that many of these immigrants would supplement the domestic workforce (Findlay and McCollum, 2013; Nori, 2017), especially in rural areas challenged by population aging and population decline. Immigrant repopulation of the countryside is often viewed as "demographic refill" (Hedberg and Haandrikman, 2014) in the sense that new arrivals can contribute to economic development and redevelopment with their skills, their external networks, and their market connections (Carson et al., 2016; Eimermann, 2016; Hedberg et al., 2012).

Many immigrants also have a strong entrepreneurial spirit. Some research concludes that immigrants are even more likely to become entrepreneurs than native-born citizens (e.g., Irastorza and Pena, 2014). As Munkejor (2017) found in a study of rural entrepreneurship in Norway, if supported by their rural communities, immigrants may successfully create and exploit entrepreneurial opportunities, and, through the entrepreneurship processes, may help rebuild these communities. According to Chun and Watanbe (2012), the establishment of new businesses has a positive influence on employment and welfare in rural areas.

\section{Immigration and rural Sweden}

As noted above, Sweden has welcomed a large number of immigrants in recent years, most of whom are now concentrated in urban areas. Their integration into Swedish work and culture has been much studied. However, less is known about the immigrants who have settled in rural areas of Sweden, especially the immigrants who arrived in the last ten years as war refugees. More research is needed on how they have contributed to the Swedish agri-sector.

\section{Research questions}

In this paper, we examine the immigrant agricultural entrepreneur in Sweden. Our two questions are the following:

- Why do immigrants become entrepreneurs in the agri-food sector in Sweden?

- Which business values do immigrant entrepreneurs in the agri-food sector in Sweden support?

\section{Methodology}

We collected the data for this paper in interviews with immigrant agricultural entrepreneurs (asylum seekers) in various rural areas of Sweden. Taking a qualitative research approach, we sought to record and interpret the experiences of this group of entrepreneurs in order to understand why they became entrepreneurs and what their main business values are. We conducted 25 semistructured, in-depth interviews in which our open-ended questions allowed us to depart from the interview guide when topics of interest arose spontaneously (Gill et al., 2008).

We used purposeful sampling to select the respondent candidates (Patton, 2002). Because the EU's General Data Protection Regulation prohibited us from searching immigrant records, we referred to local newspapers that had featured the success stories of agricultural immigrant entrepreneurs. We also used the snowball research strategy (Atkinson and Flint, 2001) with various social media and personal networks to identify possible respondents.

The 25 ( 21 men and 4 women) interviews were conducted in the autumn and winter of 2018 by telephone and in face-to-face workplace interviews. Each interview lasted from 30 to 60 minutes. 
The interviews began by explaining the purpose of the research to the respondents. The interview guide consisted of a number of questions about each respondent's, background, education, family, previous work experience, and new work experience in the agri-food sector in Sweden. The interviews focused on the respondents' reasons for entering the agri-food sector and the business values most important to them. As necessary, the interview questions were adapted to specific respondent situations.

The interviews, which were tape-recorded, were primarily conducted in Arabic languages. The respondents felt more comfortable answering the questions in their first language (rather than Swedish). The interviewer also took notes during the interviews. After the interviewers were transcribed, content analysis was used to interpret the texts. For this paper, the respondents' comments have been translated to English. Respondents' names are not used; the comments are numbered for internal identification.

\section{Research results and discussion}

We present our results and discussion pertaining to the agricultural entrepreneurs in four sections: Personal characteristics; previous entrepreneurship experience; Entrepreneurship motivation; and Business values in the agri-food business.

\section{Personal characteristics}

An immigrant entrepreneur is a business owner who works permanently in a foreign country and engages in profit-seeking activities characterized by economic innovation and organizational creativity (Vinogradov, 2011; Volery, 2007). There is considerable variation in how immigrants create and/or find work opportunities. How they respond to these opportunities also varies because of many influential factors. These factors include personal characteristics of age, education, previous work experience, work ambition, and, not least, the place where they settle (Storti, 2014). The respondents in this research, who came from Syria, Palestine, and Lebanon, had immigrated to Sweden as refugees seeking asylum. For them, entrepreneurship was an entry point to employment that offered them a chance to have a safe and stable life.

Table 1 lists data about the 25 respondents in this research. In their home countries, two respondents were teachers, one was an accountant, and three were engineers; these highly educated respondents also became agricultural entrepreneurs. The majority of the participants had less than 12 years of education in their home countries; only some had education related to the agri-food sector. None of the respondents, however, thought this lack of education or their education in an unrelated field was a barrier to their entrepreneurial performance. This conclusion is supported by Efendic et al. (2016), who studied native and immigrant CEOs of small firms.

Nineteen of the business are owned by men, one by a woman, and five by husband-wife or brother-sister teams. This distribution agrees with Williams and Krasniqi's (2017) finding that male immigrants are more likely than women to become entrepreneurs in their new country. Only two of the respondents are unmarried. With one exception, all the married entrepreneurs have children. Williams and Krasniqi also found that immigrants with children are attracted to entrepreneurship that they see as a way to provided financial security for the family.

One finding of particular interest is the respondents' language proficiency in Swedish. Only one respondent has a "High" level of knowledge of Swedish; the others are fairly evenly divided between "Low" (No knowledge of Swedish) and "Middle" (basic knowledge of Swedish). Many researchers have observed (e.g., Williams and Krasniqi, 2017; Yeasmin, 2016; Zheng, 2017) that immigrants' entrepreneurial success, in part, is influenced by their fluency in their new language. However, as our interviews revealed, even the respondents with little or No knowledge of Swedish, have exploited 
entrepreneurial opportunities in the agri-food sector. It may be that other factors (previous experience in agriculture and/or entrepreneurship) are compensatory. It may also be that the agricultural entrepreneur does not need to know how to read and speak the official language of the new country.

\section{Previous entrepreneurship experience}

Many of the respondents had operated successful businesses in their home country. Starting a new business was not an especially challenging experience despite the very different business culture plus different laws, fiercer competition, and more bureaucratic regulations. Yet even the teachers, the accountant, the engineers, the florist, and the contractor launched businesses in which they had little work experience. As Baron and Markman (2000) found, business success is more likely when entrepreneurs, among other things, have relevant previous experience in the field of their endeavor. However, previous entrepreneurship experience could compensate for lack of work experience. Only six of the 25 respondents had No previous entrepreneurship experience. Possibly the two most successful entrepreneurs in the group were the two dairy farmers who export products abroad. Both have previous entrepreneurial experience.

The respondents realize that running a business in Sweden is quite different from running a business in their home countries. It is not just the jumping though the bureaucratic hoops (about which nearly all of them complained). It is also the realization that they need a clear vision if they are to develop their businesses. As Barth et al. (2017) conclude, they need to act as entrepreneurs rather as producers. For entrepreneurs to grow and develop, they need some level of knowledge of, and competence in, marketing and management. Many studies have addressed this need (e.g., Lans et al., 2010).

\section{Entrepreneurship motivation}

Table 2 presents the respondents' statements and reasons for starting their businesses. The main motivating factors can be summarized as follows: the lack of other employment opportunities, the desire for work autonomy and flexibility, and the chance for a better standard of living. The respondents also mention the importance of community and family support for their businesses. Some local communities and towns have set aside farm land for immigrants, and government agencies have provide financial support (e.g., Stathopoulou et al., 2004). A supportive family also facilitates business growth (e.g., Alsos et al., 2014).

The respondents emphasize they are interested in full-time employment at companies, but the language barrier and their inability to prove their experience and education are problematic. These are typical immigrant employment obstacles. However, as Federick and Foley (2006) found, selfemployment can produce a renewed and positive sense of self-determination.

The respondents saw a self-employment opportunity when they spotted a niche market in the agri-food sector: traditional Middle Eastern food. To fill this niche, the immigrant entrepreneurs opened dairies, bakeries, and grocery stores. They cultivated fruits and vegetables used in Arabic dishes. However, some immigrant entrepreneurs have had to close their businesses mainly because they were unable to expand into the wider Swedish market.

\section{Business values in the agri-food sector}

Value in the agri-food sector refers to an increase in economic value as the result of improved product quality, safety, and customer appeal (see the agri-food chain as described by Humphrey and Memedovic, 2006). The agricultural entrepreneurs in this research play a special role in the agri-food value chain. They primarily aim to satisfy the demand for Middle Eastern food and other products as 
well as to support their traditional cultures. A secondary aim is to expand their niche market into the broader Swedish agri-food market. The Arabic bread and cheese and the special vegetable crops, produced and grown in new ways, add value to the Swedish agri-food sector. The entrepreneurs have taken advantage of the opportunity for product differentiation (Bhattacharyya, 2006; Kampen, 2011). They have also recognized the importance of "value creation," in which new value is created when unique production characteristics are used with traditional resources (Anderson, 2000).

Table 1

\section{Characteristics of immigrant entrepreneur}

\begin{tabular}{|c|c|c|c|c|c|c|c|c|c|c|}
\hline $\mathbf{N r}$ & Age & $\begin{array}{c}\text { Gende } \\
\mathbf{r}\end{array}$ & Orig. & $\begin{array}{c}\text { Family } \\
\text { sit. }\end{array}$ & $\begin{array}{l}\text { Nr. of } \\
\text { child. }\end{array}$ & $\begin{array}{l}\text { Educ. } \\
\text { level* }\end{array}$ & $\begin{array}{l}\text { Back- } \\
\text { ground }\end{array}$ & $\begin{array}{l}\text { Entr. } \\
\text { Exp. }\end{array}$ & $\begin{array}{l}\text { Est. } \\
\text { year }\end{array}$ & Lang. ** \\
\hline 1 & 34 & Man & Syria & Single & - & High & Account. & No & 2017 & Low \\
\hline 2 & 39 & Man & Syria & Married & 4 & High & Eng.teach & No & 2017 & Middle \\
\hline 3 & 51 & Man & Syria & Married & 3 & Middle & Trade & Yes & 2017 & Middle \\
\hline 4 & 37 & Man & Syria & Married & 4 & Low & Farmer & Yes & 2018 & Low \\
\hline 5 & 45 & Woman & Syria & Married & 6 & Middle & Dairyman & Yes & - & Low \\
\hline 6 & 33 & Man & Palest. & Married & 5 & High & Elec.eng. & No & 2016 & Middle \\
\hline 7 & 43 & Man & Syria & Married & 4 & Middle & Florist & Yes & 2016 & Middle \\
\hline 8 & 57 & Man & Palest. & Married & 4 & High & Art teach. & No & 2010 & High \\
\hline 9 & 36 & Man & Syria & Married & 7 & Low & Farmer & Yes & 2017 & Low \\
\hline 10 & 42 & Man & Syria & Married & - & High & Agri.eng. & No & 2016 & Middle \\
\hline 11 & 68 & Man & Syria & Married & 6 & Middle & Farmer & Yes & 2017 & Low \\
\hline 12 & 40 & Woman & Syria & Married & 4 & Middle & Food prod. & Yes & 2017 & Low \\
\hline 13 & 40 & Man & Syria & Married & 3 & Middle & Trade & Yes & 2018 & Low \\
\hline 14 & 55 & Man & Palest. & Married & 5 & High & Farmer & Yes & - & Middle \\
\hline 15 & 39 & Man & Leban. & Married & 2 & High & Food prod. & Yes & - & High \\
\hline 16 & 45 & Woman & Syria & Married & 2 & Middle & Food prod. & Yes & 2017 & Middle \\
\hline 17 & 53 & Woman & Syria & Married & 7 & Low & Farmer & Yes & 2018 & Low \\
\hline 18 & 53 & Man & Syria & Married & 4 & Middle & Contractor & Yes & 2016 & Low \\
\hline 19 & 58 & Man & Syria & Married & 4 & High & Agri. Eng. & Yes & 2018 & Middle \\
\hline 20 & 26 & Man & Syria & Married & 1 & High & Dairy man & Yes & - & Middle \\
\hline 21 & 48 & Man & Syria & Married & 3 & Low & Farmer & Yes & - & Low \\
\hline 22 & 58 & Man & Syria & Married & 5 & Low & Farmer & Yes & - & Low \\
\hline 23 & 53 & Man & Syria & Married & 6 & Low & Farmer & Yes & - & Low \\
\hline 24 & 55 & Man & Syria & Married & 6 & Low & Farmer & Yes & 2018 & Low \\
\hline 25 & 22 & Man & Syria & Single & - & Middle & Student & No & 2016 & Middle \\
\hline
\end{tabular}

* Education level: Low - fewer than 12 years in school, Middle - 12 years in school, High - university study.

**Language ability: Low - only first language, Middle - basic knowledge in Swedish language, High - fluent in Swedish or/and more languages. 
The agricultural entrepreneurs: Business description and motivating factors

\begin{tabular}{|c|c|}
\hline Brief description of the business & Illustrative statements/or reasons for starting a business \\
\hline $\begin{array}{l}\text { Manufacturing of soft bread and fresh } \\
\text { pastries }\end{array}$ & $\begin{array}{l}\text { A self-employed job is a good solution in a new country because } \\
\text { it is hard to find a job as an employee. There is a need for } \\
\text { Arabic bread in the market. }\end{array}$ \\
\hline $\begin{array}{l}\text { Cultivation of vegetables in greenhouses } \\
\text { and outdoors }\end{array}$ & I miss the taste of my country's vegetables, the fresh ones. \\
\hline Honey production & $\begin{array}{l}\text { He has a honey production training course that motivates him in } \\
\text { this business. }\end{array}$ \\
\hline $\begin{array}{l}\text { Cultivation different kinds of Syrian } \\
\text { vegetables }\end{array}$ & This is simply his job and he likes it. \\
\hline $\begin{array}{l}\text { Dairy production; Arabic cheeses, Halomi } \\
\text { cheeses, yoghurt, butter, cream. }\end{array}$ & $\begin{array}{l}\text { We don't want to stay at home and do nothing. We don't want } \\
\text { just to take aid from the government. We want to be } \\
\text { independent... We also want a better life for our children. }\end{array}$ \\
\hline Manufacture of dairy products. & $\begin{array}{l}\text { "I have experience as a milk product producer. My friends } \\
\text { encouraged me to start to start a business together. This was } \\
\text { the start of my business. }\end{array}$ \\
\hline $\begin{array}{l}\text { Selling flower and plants. Organizing } \\
\text { weddings and other events. }\end{array}$ & $\begin{array}{l}\text { I could not find a job, and since I like working with flowers. I } \\
\text { started a business. }\end{array}$ \\
\hline $\begin{array}{l}\text { Dairy production according to family } \\
\text { recipe from Nablus City }\end{array}$ & $\begin{array}{l}\text { The idea started when our children missed the special Nablus } \\
\text { cheese from our home country... There is a need in the market. }\end{array}$ \\
\hline $\begin{array}{l}\text { Mushroom production. Special kinds of } \\
\text { mushroom; Oyster mushroom. }\end{array}$ & $\begin{array}{l}\text { I'm a farmer and I wanted to have the same job here... due to a } \\
\text { water shortage in Gotland [a major region], I thought it would } \\
\text { be a good idea to grow mushrooms. Mushrooms don't need as } \\
\text { much water as vegetables. }\end{array}$ \\
\hline $\begin{array}{l}\text { Cultivation of various Syrian vegetables. } \\
\text { Aquaponics project for kids. }\end{array}$ & $\begin{array}{l}\text { I did not want to stay at home and do nothing... I'm an } \\
\text { agriculture engineer, and I have many business ideas. }\end{array}$ \\
\hline Cultivation of various Syrian vegetables & $\begin{array}{l}\text { I have experiences in the agricultural field, and I think that } \\
\text { business in the agriculture sector has a potential future... I want } \\
\text { to be independent and do not like to be an employee." }\end{array}$ \\
\hline $\begin{array}{l}\text { Selling fresh meat, chicken, and fish. } \\
\text { Serving different foods. }\end{array}$ & $\begin{array}{l}\text { We do not want to be unemployment and live on financial } \\
\text { support...we could not get work because of the language... We } \\
\text { thought it would be easier if we started our own business. }\end{array}$ \\
\hline $\begin{array}{l}\text { Cafeteria offers creative ice cream, fruit } \\
\text { salads, and pancakes. }\end{array}$ & $\begin{array}{l}\text { We wanted to start a creative business...We have friends in } \\
\text { Sweden who have been living here for a long time. They helped } \\
\text { us to start our business. }\end{array}$ \\
\hline $\begin{array}{l}\text { Making a small agricultural tourist village } \\
\text { with many kinds of vegetables, flowers, } \\
\text { herbs, and fruit trees from Mediterranean } \\
\text { cities. }\end{array}$ & $\begin{array}{l}\text { I have been an entrepreneur for more than } 30 \text { years in many } \\
\text { different countries. }\end{array}$ \\
\hline Honey producing, exporting, and selling & $\begin{array}{l}\text { I wanted to try the Swedish market as a first step, and then } \\
\text { expand the business to Norway. }\end{array}$ \\
\hline $\begin{array}{l}\text { Food truck with different food dishes. } \\
\text { Preparation of food for events and fairs. }\end{array}$ & $\begin{array}{l}\text { We have experience in running a restaurant in Syria...The Syrian } \\
\text { food is delicious. There is a demand from the Arabic and } \\
\text { Swedish customers for this kind of food. }\end{array}$ \\
\hline $\begin{array}{l}\text { A farm with different kinds of vegetables; } \\
\text { cucumbers, zucchini, tomatoes, } \\
\text { watermelons, beans, etc. }\end{array}$ & $\begin{array}{l}\text { It was just not possible to get a job... We had an idea and } \\
\text { wanted to achieve something in this country. }\end{array}$ \\
\hline $\begin{array}{l}\text { A farm with different kinds of vegetables } \\
\text { grown in five greenhouses. }\end{array}$ & $\begin{array}{l}\text { "The municipality provided me with some land that I could use } \\
\text { to grow and build greenhouses. }\end{array}$ \\
\hline Grocery store & $\begin{array}{l}\text { It was very difficult to find a job in the agriculture sector so I } \\
\text { preferred to have my own business. }\end{array}$ \\
\hline Dairy production & $\begin{array}{l}\text { I started to work as an employee, but it was too hard... I also } \\
\text { like to run my own business...I worked as a dairy manager for } \\
\text { five years. }\end{array}$ \\
\hline A farm with different kinds of vegetables. & It is easier in a new country to have your own business. \\
\hline A Farm with a greenhouse. & $\begin{array}{l}\text { The municipality provided me with a piece of land that I could } \\
\text { use. }\end{array}$ \\
\hline $\begin{array}{l}\text { Renovating an old farm and growing } \\
\text { vegetables. }\end{array}$ & $\begin{array}{l}\text { A friend offered me a field to grow vegetables... I had previous } \\
\text { experience. }\end{array}$ \\
\hline $\begin{array}{l}\text { A farm with different kinds of vegetables: } \\
\text { zucchini, corn, beans, carrots. etc. }\end{array}$ & $\begin{array}{l}\text { It is better to have your own business, compared to being } \\
\text { employed... As an entrepreneur I have several options to } \\
\text { develop a better future. }\end{array}$ \\
\hline $\begin{array}{l}\text { Importing and selling Halal meat and } \\
\text { chicken. }\end{array}$ & $\begin{array}{l}\text { Having your own company means you can develop opportunities } \\
\text { and new things...There is a big demand for Arabic food. }\end{array}$ \\
\hline
\end{tabular}




\section{Conclusions and recommendations}

1) Personal characteristics and entrepreneurship experience are factors that most influence immigrant entrepreneurship performance.

2) Immigrants choose self-employment in the agri-food sector area for three mains reasons: inability to find full-time employment, financial and other support, and prior employment experience.

3) Immigrant entrepreneurs strengthen a country's cultural and food diversity when they introduce new agri-food products. They strengthen economies by adding jobs and opening markets.

4) A development model is needed that can help immigrant entrepreneurs successfully run businesses and create job opportunities.

5) To support immigrant entrepreneurship, new government reforms and policies are needed.

\section{Bibliography}

1. Alsos, G. A., Carter, S., Ljunggren, E. (2014). Kinship and Business: How Entrepreneurial Households Facilitate Business Growth. Entrepreneurship \& Regional Development, Volume 26, Issue 1-2, pp. 97-122.

2. Anderson, A.R. (2000). Paradox in the Periphery: An Entrepreneurial Reconstruction? Entrepreneurship and Regional Development. Volume 12, Issue 2, pp. 91-109.

3. Atkinson, R., Flint, J. (2001). Accessing Hidden and Hard-to-Reach Populations: Snowball Research Strategies. Social Research Update, Volume 33, pp. 1-5.

4. Barron, R., Markman, G. (2000). Beyond Social Capital: How Social Skills Can Enhance Entrepreneurs' success. Academy of Management Executive, Volume 14, Issue 1, pp. 106-116.

5. Barth, H., Ulvenblad, P-O., Ulvenblad, P. (2017). Towards a Conceptual Framework of Sustainable Business Model Innovation in the Agri-Food Sector: A Systematic Literature Review. Sustainabiity, 9, 1630.

6. Bhattacharyya, S. (2006). Entrepreneurship and Innovation: How Leadership Style Makes the Difference? Vikalpa. Volume 31, Issue 1, pp. 107-115

7. Carson, D. A., Cleary, J., de la Barre, S., Eimermann, M., Marjavaara, R. (2016). New Mobilities-New Economies? Temporary Populations and Local Innovation Capacity in Sparsely Populated Areas. Settlements at the Edge: Remote Human Settlements in Developed Nations. Cheltenham: Edward Elgar, Cheltenham. pp. 178-206.

8. Chun, N., M. Watanabe. (2012). Can Skill Diversification Improve Welfare in Rural Areas? Evidence from Bhutan. Journal of Development Effectiveness, Volume 4, Issue 2, pp. 214-234.

9. Eimermann, M. (2016). Two Sides of the Same Coin: Dutch Rural Tourism Entrepreneurs and Countryside capital in Sweden. Rural Society, Volume 25, Issue 2, pp. 55-73.

10. Efendic, N., Andersson, F. W., Wennberg, K. (2016). Growth in First- and Second-Generation Immigrant Firms in Sweden. International Small Business Journal, Volume 34, Issue 8, pp. 1028-1052.

11. EIP-AGRI. (2016). Focus Group New Entrants into Farming Final Report. Resource Document. European Commission.

12. Eurostat. (2018). Asylum Decisions in the EU: EU Member States Granted Protection to More than Half a Million Asylum Seekers in 2017: Almost One-Third of the Beneficiaries were Syrians. Eurostat News Release.

13. FAO. (2018). World Food and Agriculture - Statistical Pocketbook 2018. Rome. pp. 254 Licence: CC BY-NC-SA 3.0 IGO

14. Findlay, A., McCollum, D. (2013). Recruitment and Employment Regimes: Migrant Labour Channels in the UK's Rural Agribusiness Sector, from Accession to Recession. Journal of Rural Studies, Volume 30, pp. 10-19.

15. Frederick, H. H., Foley, D. (2006). Indigenous Populations as Disadvantaged Entrepreneurs in Australia and New Zealand. The International Indigenous Journal of Entrepreneurship, Advancement. Strategy and Education, Volume 1, Issue 1, pp. 1-16.

16. Gill, P., Stewart, K., Treasure, E., Chadwick, B. (2008). Methods of Data Collection in Qualitative Research. Interviews and Focus Groups. British Dental Journal, Volume 204, Issue 6, pp. 291-295.

17. Gries, T., Naude, W. (2011). Entrepreneurship and Human Development: A Capability Approach. Journal of Public Economics, Volume 95, Issue 3, pp. 216-224.

18. Hedberg, C., Forsberg G., Najib, A. (2012). When the World Goes Rural: Transnational Potentials of International Migration in Rural Swedish labour. GeoJournal Library, Volume 103, pp. 125-142

19. Hedberg, C., Haandrikman, K. (2014). Repopulation of the Swedish Countryside: Globalisation by International Migration. Journal of Rural Studies. Volume 34, pp. 128-138.

20. Hedlund M., Lundholm, E. (2015). Restructuring of Rural Sweden - Employment Transition and OutMigration of Three Cohorts born 1945-1980. Journal of Rural Studies, Volume 42, pp. 123-132

21. Humphrey, J., Memedovic, O. (2006). (Working paper). Retrieved from United Nations Global Value Chains in the Agrifood Sector Industrial Development Organization website: 
http://www.unido.org/fileadmin/user_media/Publications/Pub_free/Global_value_chains_in_the_agrifood_se ctor.pdf

22. Irastorza, N., Pena, I. (2014). Earnings of Immigrants: Does Entrepreneurship Matter? The Journal of Entrepreneurship, Volume 23, Issue 1, pp. 35-56.

23. Jordbruksverket. (2018). Sveriges officiella statistik.

24. Kampen, K. (2011). Financial Analysis of Three Value-Added Dairy Enterprises in Vermont, Wisconsin, and New York. PhD thesis. San Louis Obispo, CA; California Polytechnic State University.

25. Lans, T., Biemans, H., Mulder, M., Verstegen, J. (2010). Self-Awareness of Mastery and Improvability of Entrepreneurial Competence in Small Businesses in the Agrifood Sector. Human Resource Development Quarterly, Volume 21, Issue 2, pp. 147-168.

26. Lans, T., Seuneke, P., Klerkx, L. (2013). Agricultural Entrepreneurship. In E. G. Carayannis (Ed.), Encyclopedia of Creativity, Invention, Innovation, and Entrepreneurship (pp. 44- 49). Berlin, Heidelberg: Springer.

27. Munkejord, M. C. (2017). Becoming Spatially Embedded: Findings from a Study on Rural Immigrant Entrepreneurship in Norway. Entrepreneurial Business and Economics Review, Volume 5, Issue 1, pp. $111-130$.

28. Nori, M. (2017). The Shades of Green: Migrants' Contribution to EU Agriculture. Context, Trends, Opportunities, Challenges. Florence, Migration Policy Centre.

29. Patton, M. Q. (2002). Two Decades of Developments in Qualitative Inquiry: A Personal, Experiential Perspective. Qualitative Social Work, Volume 1, Issue 3, pp. 261-283.

30. Pindado, E., Sanchez, M. (2017). Researching the Entrepreneurial Behaviour of New and Existing Ventures in European Agriculture. Small Business Economics, Volume 49, pp. 421-444.

31. Seuneke, P., Lans, T., Wiskerke, J. S. (2013). Moving Beyond Entrepreneurial Skills: Key Factors Driving Entrepreneurial Learning in Multifunctional Agriculture. Journal of Rural Studies, Volume 32, pp. $208-219$.

32. Stathopoulou, S., Psaltopoulos, D., Skuras, D. (2004). Rural Entrepreneurship in Europe. A Research Framework and Agenda. Journal of Entrepreneurial Behaviour \& Research, Volume 10, Issue 6, pp. 404-425.

33.Storti, L. (2014). Being an Entrepreneur: Emergence and Structuring of Two Immigrant Entrepreneur Groups. Entrepreneurship and Regional Development, Volume 26, Issue 7-8, pp. 521-545.

34. Vik, J., McElwee, G. (2011). Diversification and the Entrepreneurial Motivations of Farmers in Norway. Journal of Small Business Management, Volume 49, Issue 3, pp. 390-410.

35. Vinogradov, E. (2011). Ethical Aspects of Research on Ethnic/Immigrant Entrepreneurship. Entrepreneurship Research Journal, Volume 1, Issue 3. doi:10.2202/2157-5665.1017

36. Volery, T. (2007). Ethnic Entrepreneurship. A Theoretical Framework. In L. P. Dana (Ed.). Handbook of Research on Ethnic Minority Entrepreneurship: A Co-evolutionary View on Resource Management (pp. 30-41). Northhampton, MA: Edward Elgar Publishing.

37. Williams, N., Krasniqi, B. A. (2017). Coming Out of Conflict: How Migrant Entrepreneurs Utilise Human and Social Capital. Journal of International Entrepreneurship, Volume 16, Issue 2, pp. 301-323.

38. Yeasmin, N. (2016). The Determinants of Sustainable Entrepreneurship of Immigrants in Lapland: An Analysis of Theoretical Factors. Entrepreneurial Business and Economics Review, Volume 4, Issue 1, pp. 129-159.

39.Zheng, Y. (2017). How Immigrants Invent: Evidence from Sweden. Lund: Media-Tryck, Lund University. 